\section{Pilz ergänzt Neurodermitis-Puzzle}

\section{Der opportunistische Hefepilz Malassezia gilt als Triggerfaktor des} atopischen Ekzems. Besonders Patienten mit Neurodermitis im KopfHals-Bereich und hohem Serum-IgE reagieren auf Malassezia - eine Behandlung mit dem Antimykotikum Ketokonazol kann das klinische Bild verbessern. Aber was ist mit Patienten, die nicht in diese Gruppe fallen?

\section{S} chwedische Forscher legten jetzt eine ausführliche Studie vor, bei der sie 131 Neurodermitiker auf ihre Reaktivität gegen Malassezia testeten. 98 Patienten waren mit und 33 ohne Ekzem im Kopf-Hals-Bereich, bei 91 lag das Serum-IgE im mittleren bis hohen Bereich, bei 40 war es sehr niedrig. Die Forscher wandten drei Testverfahren an: Bestimmung von spezifischem Serum-IgE durch ELISA, Pricktest und Patchtest. 14 Patienten mit seborrhoischem Ekzem und 33 Gesunde dienten als Kontrollen.

$76 \%$ der Patienten waren in mindestens einem der Tests positiv. 51\%

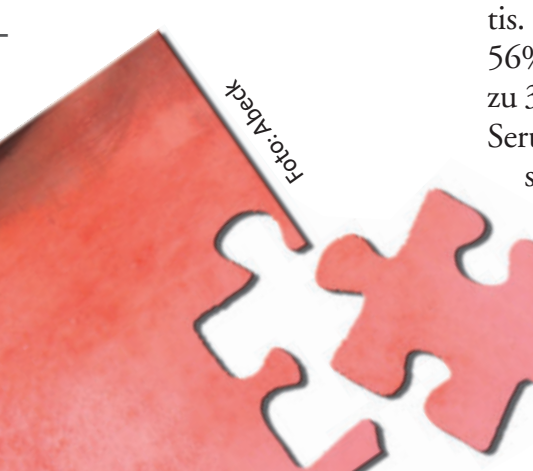
den Patchtest. Von den Kontrollprobanden reagierte lediglich ein Patient mit seborrhoischem Ekzem und ein Gesunder auf den Patchtest. In den Subgruppen mit oder ohne KopfHals-Ekzem beziehungsweise mit mittlerem bis hohem oder sehr niedrigem 56\% zu 36\% und beim Patchtest 41\% zu 30\%. Bei Patienten, die sehr niedriges Serum-IgE hatten, war der Patchtest am sensitivsten: 23\% dieser Subgruppe reagierten positiv, 18\% sprachen auf den Pricktest an und nur $8 \%$ hatten nachweisbare Malassezia-Antikörper.

Fazit: Der Patchtest kann eine wichtige Ergänzung zur Diagnostik einer Malassezia-Sensibilisierung bei Neurodermitikern sein. Gerade auch bei Patienten ohne Kopf-Hals-Ekzem und mit niedrigem Serum-IgE, die als „nicht-IgE assoziiertes Atopisches-Ekzem-Syndrom " eingestuft worden wären, könnte der Pilz eine wichtige Rolle spielen.

Johansson C et al: Atopy patch test reactions to Malassezia allergens differentiate subgroups of atopic dermatitis patients. Br J Dermatol 2003; 148: 479-88

\section{Dermatitis als Preis für körperliche Frische?}

\section{Eine Dermatitis im Achselbereich tritt überdurchschnittlich häufig bei Personen mit Kontaktallergie gegen bestimmte Duftstoffe in Körpersprays auf. Welche pathogenetische Rolle dabei Zimtaldehyd spielt, eine Substanz, die in vielen handelsüblichen Deodorants enthalten ist, untersuchte eine experimentelle Provokationsstudie aus Schweden.}

$\mathrm{B}_{\mathrm{h}}^{\mathrm{c}}$ ei einer früheren Untersuchung hatten bereits zwölf von 20 getesteten Deodorants bei Personen mit einer Sensibilisierung gegen bestimmte Aromastoffe ein Ekzem in der Achselhöhle ausgelöst. Die meisten dieser Sprays enthielten mindestens eine Substanz aus der Standardepikutantestreihe der North American Contact Dermatitis Group (NACDG). Ob der Duftstoff oder andere Komponenten des Deodo- rants zur Hautirritation führte, blieb ungeklärt.

Eine Arbeitsgruppe der schwedischen Universität Malmö hat jetzt speziell die Rolle von Zimtaldehyd bei der Entwicklung einer Dermatitis im Achselbereich unter die Lupe genommen. Es nahmen 37 Patienten an der Untersuchung teil, davon 17 mit nachgewiesener Sensibilisierung gegenüber Zimtaldehyd. Deodorants mit Zimtaldehyd in den Konzentrationen 0,1\%, 0,032\% und $0,01 \%$ wurden jeweils zweimal täglich über 2 Wochen in der Achselhöhle aufgetragen. Alle sensibilisierten Testpersonen entwickelten dort spätestens nach 3 Wochen ein infiltriertes, meist papulöses Ekzem. Die Kontrollgruppe blieb symptomfrei.

Fazit: Achselsprays, die Zimtaldehyd in einem Konzentrationsbereich zwischen $0,01 \%$ und $0,32 \%$ enthalten, können bei täglich zweimaliger Anwendung auf sensibilisierter Haut nach wenigen Wochen eine Dermatitis auslösen.

Bruze $\mathbf{M}$ et al. Deodorants: an experimental provocation study with cinnamic aldehyde. J Am Acad Dermatol 2003; 48: 194-200 